\title{
An Epidemic of Caprine Arthritis Encephalitis in Japan: Isolation of the Virus
}

\author{
Misako KONISHI ${ }^{1)}$, Satoko TSUDUKU ${ }^{1,2)}$, Makoto HARITANI ${ }^{1)}$, Kenji MURAKAMI ${ }^{1)}$, Takamitsu TSUBOI ${ }^{1}$, \\ Chiho KOBAYASHI $^{3)}$, Keiichi YOSHIKAWA ${ }^{3)}$, Kumiko M. KIMURA ${ }^{1)}$ and Hiroshi SENTSUI ${ }^{1) *}$ \\ ${ }^{1)}$ National Institute of Animal Health, Tsukuba, Ibaraki 305-0856, ${ }^{2}$ Kenhoku Livestock Hygiene Service Station, Mito, Ibaraki 310-0851 \\ and ${ }^{3)}$ Matsumoto Livestock Hygiene Service Station, Matsumoto, Nagano 390-0851, Japan
}

(Received 2 December 2003/Accepted 23 March 2004)

ABSTRACT. A disease characterized by arthritis of carpal joints and occasionally by pneumonia was seen among goats on a farm in Nagano prefecture of Japan in the summer of 2002. Serological investigation was done on 30 goats, that is one group on the farm by agar gel immunodiffusion tests using maedi-visna virus as the antigen, and 19 goats were positive. The caprine arthritis encephalitis vi rus genome was detected in peripheral blood leukocytes from several antibody-positive goats. Two goats among them were necropsied and usedfor pathological tests and virus isolation. The isolated virus was serially propagated in fetal lamb lung cell cultures. Goats inoculated with the culture fluid became antibody positive. These results suggested that a CAEV-infected goat had been introduced accidentally to the farm and that subclinical infection occurred among the flock.

KEY WORDS: arthritis, caprine arthritis encephalitis, goat, lentivirus, maedi-visna virus.

J. Vet. Med. Sci. 66(8): 911-917, 2004

Caprine arthritis-encephalitis (CAE) is a disease of domestic goats caused by a lentivirus of the family Retroviridae [5, 6]. CAE has been identified in most goatrearing countries around the world $[2,15]$. Most infected goats develop specific antibodies which persist for life [1, $6]$, and the detection of antibodies can be taken as proof of the presence of the viral infection [3, 15]. However, only some of the infected goats, less than $10 \%$, develop clinical disease characterized by chronic persistent arthritis, mastitis, respiratory distress and encephalitis [6, 7, 15, 16, 24]. The time between the moment of infection and the development of detectable levels of antibody and the onset of clinical disease may vary from months to years $[1,18]$. Japan had been considered to be free from the disease because clinical symptoms that suggest CAE had not been reported among goats. However, a disease characterized by cachexia and synovitis, especially of carpal joints, and occasionally by mastitis and/or pneumonia was seen among goats on a farm in Nagano prefecture of Japan in the summer of 2002. The clinical symptoms indicated that the disease was CAE. Caprine arthritis-encephalitis virus (CAEV) infection is persistent, so that antibody detection is a valuable serological tool for identifying virus carriers. CAEV and maedi-visna virus (MVV) are antigenically indistinguishable by methods that employ polyclonal antisera, though the close antigenic relationship between CAEV and MVV does not extend to identical efficiencies in their use for detection of heterologous antibody [12]. We investigated the cause of the disease by serological survey using MVV as an antigen and virus isolation from the lesions of affected goats. This paper presents the results of virological and serological studies of the disease in goats and the isolated virus.

\footnotetext{
* Correspondence to: Sentsui, H.

PRESENT ADDRESS: School of Veterinary Medicine, Nihon University, 1866 Kameino, Fujisawa, Kanagawa 252-8510, Japan.
}

\section{MATERIALS AND METHODS}

Sampling: About two hundred goats were kept for breeding in the farm and clinical abnormality with arthritis of carpal joints and pneumonia has been occasionally observed among them since several years ago. They were suspected to be an infectious disease, but as far as bacteriological examination by the animal hygiene service station, pathogenic agent was not detected. There were several goats with arthritis of carpal joints in the summer in 2002. Two goats among them, 5 years old and 6 years old, especially showing severe arthritis in carpal joints were euthanized and necropsied. Brains, lungs, udders, cartilages, synovial membranes and carpal joints were collected for pathological observation, and peripheral blood, joint fluids and synovial membrane were collected for virus isolation.

To determine the prevalence of CAE on the farm, blood samples were collected from 30 goats that had been kept in a group with the two arthritic goats, and the presence of infected animals was investigated by the agar gel immunodiffusion (AGID) test and polymerase chain reaction (PCR). Blood was collected from the jugular vein and placed in a plain tube for serum collection and an EDTA-containing tube for virus isolation and PCR testing.

To examine the prevalence of the disease outside of the farm, blood samples were collected from a total of 86 goats on 16 farms in Ibaraki prefecture where the National Institute of Animal Health is situated, with the help of Kenhoku Livestock Hygiene Service Station.

Cell cultures: Fetal lamb lung (FLL) cell cultures were used for virus isolation and cultivation. FLL cell cultures were prepared by standard tissue culture methods and used within 20 passages. For virus isolation, FLL cells passaged less than 5 times were used. The cells were cultivated in a medium consisting of $10 \%$ fetal calf serum and $90 \%$ Eagle's minimum essential medium (Nissui pharmaceutical Co., 


\section{Ltd., Tokyo, Japan).}

Virus and antigen preparation: MVV, which has common antigenicity with CAEV [12], was used as an antigen for the serological test. The virus was kindly supplied by Dr. M. Onuma of Hokkaido University and propagated in FLL cells. The AGID test was done for serological survey [8]. Since FLL did not produce cytopathic effect (CPE) clearly when inoculated with the viral fluid, the cell cultures were co-cultivated with virus-infected cells and used as the material for AGID antigen. Briefly, virus-infected FLL cells that began to show CPE were trypsinized and mixed with 4 or 5 fold number of normal FLL cells. Co-cultivated cells were incubated for 4 or 5 days and culture fluids were harvested when CPE appeared in more than $80 \%$ of cells. Viral fluids were concentrated as described previously for the preparation of bovine leukemia virus (BLV) antigen for the AGID test [13].

Reference antisera and serological test: Reference antisera against CAEV and MVV were supplied by Dr. D. P. Knowles, Jr. of the OIE Reference Laboratory for CAE and maedi-visna (Animal Disease Research Unit, USDA, ARS, Washington State University, Pullman, WA, U.S.A.). The antibody survey for CAEV was done using the AGID test. One goat's serum yielded a single dense precipitation line which connected to both of the reference sera in the AGID test. So it was determined to the positive control serum for the AGID test. AGID tests were performed with minor modifications of the method for BLV that was reported by Kono et al. [14]. The gel consisted of $1.0 \%$ noble agar and $8.5 \% \mathrm{NaCl}$, and $\mathrm{pH}$ was adjusted to $8.2-8.6$ by Tris-HCl. The wells were $5 \mathrm{~mm}$ in diameter and six circumferential wells were placed at a distance of $3 \mathrm{~mm}$ from the central well. The antigen was placed in the central well and positive control serum was placed in alternate exterior wells. Serum samples were placed in the remaining three wells. The gel diffusion plate was allowed to stand at room temperature for $48 \mathrm{hr}$ and formed precipitation lines were observed. If the sample formed a complete precipitation line connected to the control positive line, it was judged to be positive and indicated as ++. The samples that did not form a precipitation line but curved the end of control positive line slightly inside at the test serum well were judged to be weakly positive and indicated as + (cf. Fig. 1. well No. 6).

Virus isolation: Carpal joint fluid, homogenized synovial membrane and peripheral blood leukocytes (PBL) of two goats that suffered from arthritis and necropsied were used for virus isolation. PBL were adjusted to $1 \times 10^{6} / \mathrm{m} l$ and 2 $\mathrm{m} l$ of that were co-cultivated with $3.5 \mathrm{~cm}$ diameter petri dish of FLL cells. The carpal joint fluid and homogenized synovial membrane were directly added to the FLL cell culture. The FLL cells were passaged several times and the possibility of CAEV infection was investigated by PCR, the indirect immunofluorescence (IIF) test, formed syncytium observation and electron microscopic (EM) observation.

Extraction of DNA from peripheral blood leukocytes and cultivated cells: PBL were separated by centrifugation from EDTA-treated blood after lysis of erythrocytes by mixing with two volumes of $0.83 \% \mathrm{NH}_{4} \mathrm{Cl}$ solution for $5 \mathrm{~min}$ and washed 4 times in PBS by centrifugation at 2,000 $\times \mathrm{g}$ for 5 min. In the case of cultivated cells, they were trypsinized and washed 2 times in PBS. The suspended cells were centrifuged at 2,000 $\times \mathrm{g}$ for $5 \mathrm{~min}$ in a microcentrifugation tube and DNA was extracted from the cell pellet with a DNA extraction kit SepaGene (Sanko Junyaku, Tokyo, Japan), following the manufacturer's instructions.

Polymerase Chain reaction: For nested PCR study, we modified the method described by Fieni et al. [10]. In the method, a part of gag region of CAEV was amplified using two pair of primers $[10,22]$. In the first PCR, $0.5-1 \mu \mathrm{g}$ of DNA from each sample was added to the PCR reaction mixture containing $10 \mathrm{mM}$ Tris- $\mathrm{HCl}(\mathrm{pH} 8.3), 50 \mathrm{mM} \mathrm{KCl}, 1.5$ $\mathrm{mM} \mathrm{MgCl} 2,200 \mu \mathrm{M}$ each dNTP, $0.2 \mu \mathrm{M}$ of each primer and 1.25 U of Ampli Taq Gold DNA polymerase (Applied Biosystems, Foster City, CA, U.S.A.), then adjusted the total volume to $50 \mu l$ with steriled water. The sequences of the first PCR primers were P1 (5'-caagcagcaggagggagaagctg3') and P2 (5'-tcctaccccataatttgatccac-3'), and a 296 bp product was predicted. DNA was amplified with a DNA Thermal cycler, (Gene Amp PCR System 9700, Applied Biosystems) by 1 cycle of $94 \times \mathrm{C}$ for $5 \mathrm{~min}, 34$ cycles of denaturation $\left(94^{\circ} \mathrm{C}, 30 \mathrm{~s}\right)$, annealing $\left(55^{\circ} \mathrm{C}, 30 \mathrm{~s}\right)$ and extension $\left(72^{\circ} \mathrm{C}, 90 \mathrm{~s}\right)$ and final extension $\left(72^{\circ} \mathrm{C}, 5 \mathrm{~min}\right)$. For the

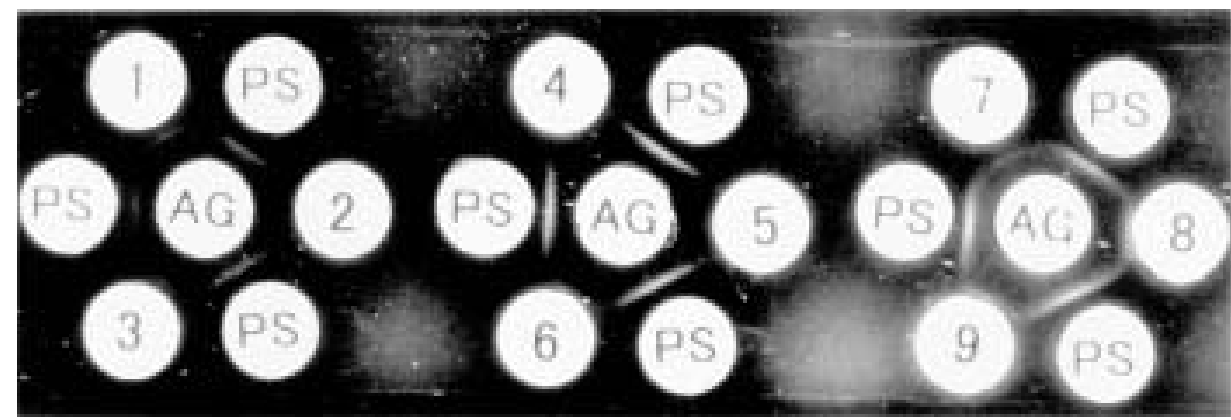

Fig. 1. Immunodiffusion test in goats. The antigen was placed in the central well (AG) and positive control serum was placed in alternate exterior wells (PS). Serum samples were placed in the remaining three wells (From 1 to 9). The gel diffusion plate was allowed to stand at room temperature for $48 \mathrm{hr}$ and formed precipitation lines were observed. 1:++, 2:-, 3:++, 4:-, 5:-, 6:+, 7:++, 8:+, 9:+. 
second PCR, $1 \mu l$ of the first PCR product were again amplified in the same conditions except $0.2 \mu \mathrm{M}$ of each primer. The sequences of the second PCR primers were P3 (5' -gttccagcaactgcaaacagtagcaatg-3') and P4 (5' -acctttctgcttcttcatttaatttccc-3'), and a 184 bp product was predicted. The PCR products were electrophoresed in $2 \%$ agarose gels and stained with ethidium bromide.

Indirect immunofluorescence tests and syncytium observation: FLL cells were inoculated with carpal joint fluid from necropsied goats and passaged 3 or 4 times. For IIF tests, the cells were washed with PBS and fixed with cold acetone for $10 \mathrm{~min}$, incubated with the control antiserum for the AGID test $\left(1: 20\right.$ dilution) at $37^{\circ} \mathrm{C}$ for $30 \mathrm{~min}$, and stained with a fluorescein-5-isothiocyanate (FITC) -conjugated rabbit Immunoglobulin $\mathrm{G}$ (IgG) fraction to goat $\mathrm{IgG}$ (Cappel: Durham, NC, U.S.A.) at $37^{\circ} \mathrm{C}$ for $30 \mathrm{~min}$, then their fluorescent staining was observed. For syncytium tests, the cells were fixed with methanol when they formed almost a full sheet, stained by Geimsa and formed syncytia were observed. As a negative control, non-infected FLL cells were used.

Electron microscopic observation: For EM observation, the infected FLL cells were detached from the petri dish with a rubber policeman. Then, the cells were fixed in $2.5 \%$ glutaraldehyde in PBS, pelleted by centrifugation, post fixed with osmium tetroxide (1\% in PBS) and embedded in Epon 812. Ultrathin sections cut from the materials were stained with uranyl acetate and lead citrate, and observed using electron microscopy.

DNA sequencing: PCR products from the second PCR were purified using QIAquick PCR Purification Kit (QIAGEN, GmbH, Hilden, Germany) according to the manufacturer's instructions. The sequencing reactions were performed by Hokkaido System Science Co., Ltd. (Sapporo, Japan). Sequences were obtained from both strands of each PCR product for verification. The nucleotide sequences were analyzed using the GENETYX-WIN ver.5.1 sequence analysis program (Software Development Co., Ltd., Tokyo, Japan).

Experimental infection of the goats: Three goats, 4-6 months old, were confirmed to be negative for CAEV by the AGID test and the PCR. All goats were inoculated intravenously with $3 \mathrm{~m} l$ of culture fluid of FLL inoculated with carpal joint fluid from a goat with clinical symptoms. They were kept in isolated pens $(3.4 \mathrm{~m} \times 3 \mathrm{~m})$. The peripheral blood was collected periodically from these goats and used for detection of the viral genome by PCR and antibody to the virus by the AGID test.

\section{RESULTS}

Clinical signs of the disease: Several goats were recognized to have arthritis of carpal joints by a veterinarian belonging to the Matsumoto Livestock Hygiene Service Station in Nagano prefecture. They were born and grew up on the farm. The disease was mild, with neither an apparent increase in temperature nor a change in appetite, and pain was not noticeable. Among these goats with arthritis, two goats which showed positive antibody respond with severe arthritis were subjected to morphological pathology. Proliferative synovitis accompanied by remarkable lymphocytic infiltration, lymphocytic interstitial pneumonitis and mastitis were observed in both animals (Yoshikawa K. et al., Abstract of 135th Meeting of the Japanese Society of Veterinary Science, pp. 75, March 2003, Tokyo).

Serological and genetic survey of goats: Thirty blood samples were collected from goats on the farm and tested by the AGID antibody (Fig. 1) and 19 samples were positive. DNA was extracted from PBL of 22 of Shiba goats ( Capra hircus) and subjected to PCR, and 8 samples were positive. Six samples were both antibody- and PCR-positive (Table 1). To investigate the prevalence of the disease in other areas, an antibody survey of goats was conducted in Ibaraki prefecture. Antibody-positive goats were detected on two of 16 farms, and the two positive farms had goats related to the farm in Nagano prefecture (Table 2). Farm G had goats that had been transferred from the farm in Nagano prefecture once, though the present positive animals were born and grew up there. The positive goats in Farm K had been kept with the goats from the farm in Nagano prefecture before

Table 1. Serological and genetical investigation of goats at risk for caprine arthritis-encephalitis virus

\begin{tabular}{|c|c|c|c|c|}
\hline \multirow{2}{*}{\multicolumn{2}{|c|}{$\frac{\text { Goat breed }}{\text { PCR }}$}} & \multicolumn{2}{|c|}{ Shiba goat } & \multirow{2}{*}{$\begin{array}{l}\text { Saanen } \\
\text { Not done }\end{array}$} \\
\hline & & + & - & \\
\hline \multirow[t]{2}{*}{ AGID } & + & 6 & 2 & 11 \\
\hline & - & 2 & 0 & 9 \\
\hline
\end{tabular}

Table 2.Serological survey of CAEV in Ibaraki prefecture

\begin{tabular}{ccc}
\hline Farm & \multicolumn{2}{c}{ Numbers of animals } \\
\hline & Positive & Tested \\
\hline A & 0 & 7 \\
B & 0 & 5 \\
C & 0 & 1 \\
D & 0 & 5 \\
E & 0 & 5 \\
F & 0 & 10 \\
G ${ }^{a}$ & 5 & 10 \\
H & 0 & 1 \\
I & 0 & 5 \\
J & 0 & 4 \\
K & $3^{\text {b) }}$ & 5 \\
L & 0 & 9 \\
M & 0 & 5 \\
N & 0 & 4 \\
O & 0 & 4 \\
P & 0 & 6
\end{tabular}

a) Goats transferred from the farm in Nagano prefecture had been present once.

b) The positive goat had been kept in other farm with the goats from the farm in Nagano prefecture before they had moved there 


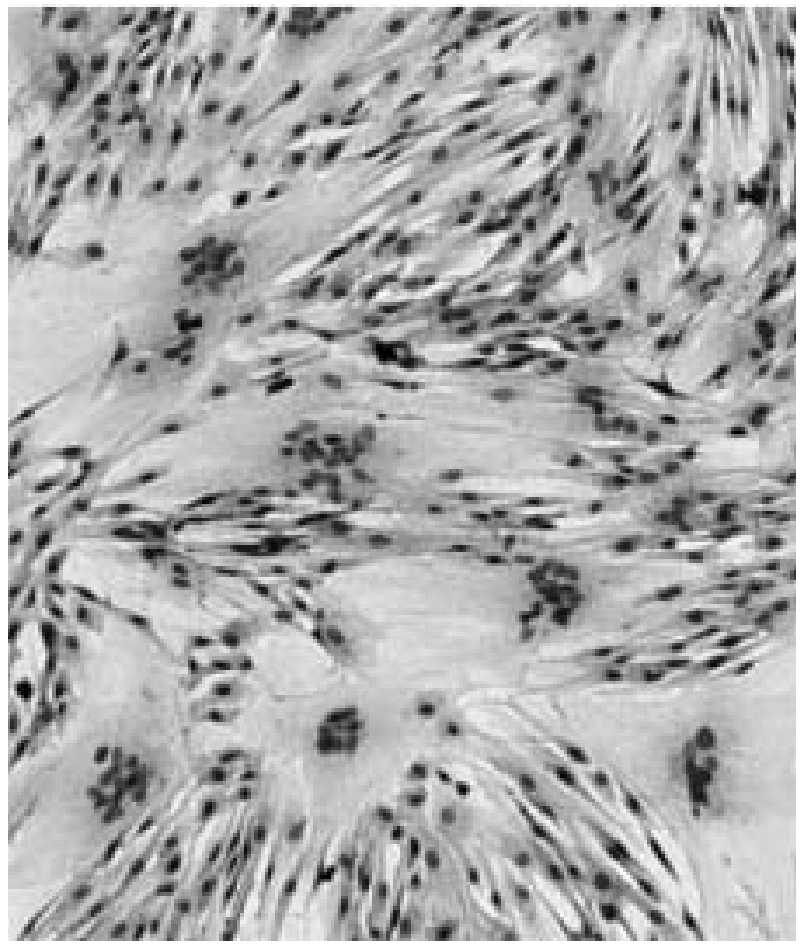

Fig. 2. Formed syncytia in FLL cells. FLL cells inoculated with carpal joint fluid from a goat with arthritis were passaged 3 times and stained with Giemsa.

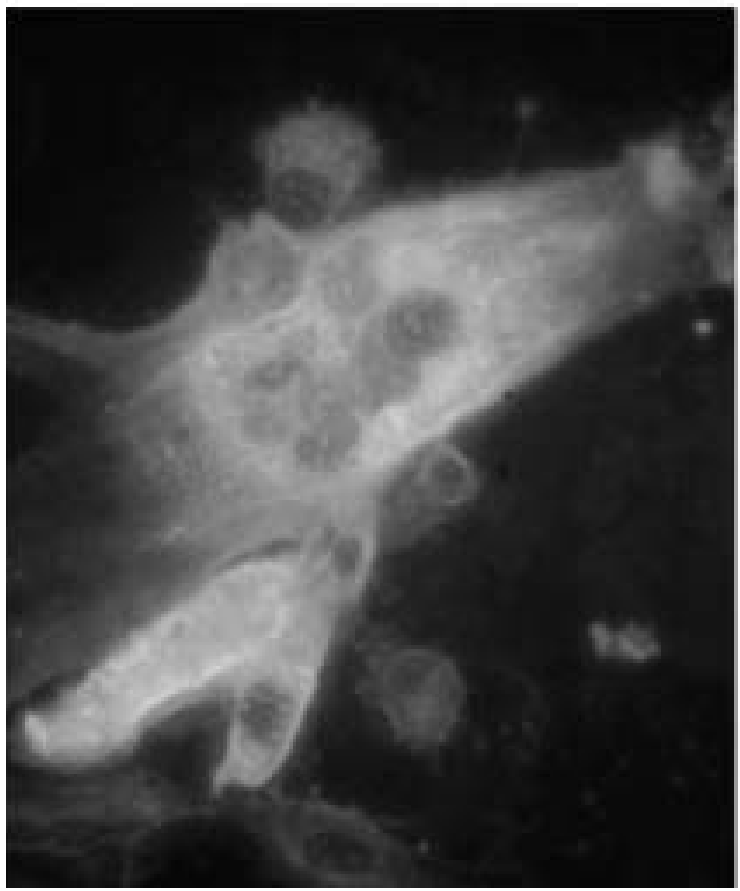

they had moved there.

Virus isolation: The FLL cells which were inoculated or co-cultivated with the carpal joint fluid, synovial membrane and PBL respectively from the necropsied two goats were passaged several times. At the third passage, these cells were stained with Gimsa and as a result, in the FLL cells inoculated with carpal joint fluid from one goat (goat No. 40), sincytia were observed (Fig. 2). They were also stained in IIF tests by the positive control serum of AGID test (Fig. $3)$.

DNA extracted from these cells became positive at the first PCR. Ultrathin sections cut from the FLL cell were observed using EM and buds of the virus on the cells membrane were observed (Fig. 4). The particles were within the range from 90 to $150 \mathrm{~nm}$ in diameter. The virus was subsequently propagated in them after several passages.

Three goats inoculated with culture fluid of the infected FLL cells did not show any clinical symptoms for one year. However, the antibody was detected at 3 months after inoculation by the AGID test and the CAEV genome was amplified from PBL from all of them by the nested PCR. The positive reactions of these tests were not stable and sometimes turned negative in two of the three animals.

PCR and sequence analysis of PCR product: By the PCR, a 296 bp fragment was amplified from the DNA of the FLL cells co-cultivated with PBL or inoculated with the carpal joints of arthritic goats by the first PCR, and a $184 \mathrm{bp}$ fragment was produced by second PCR. The PCR was specific not only for CAEV but also MVV (Fig. 5). No fragment

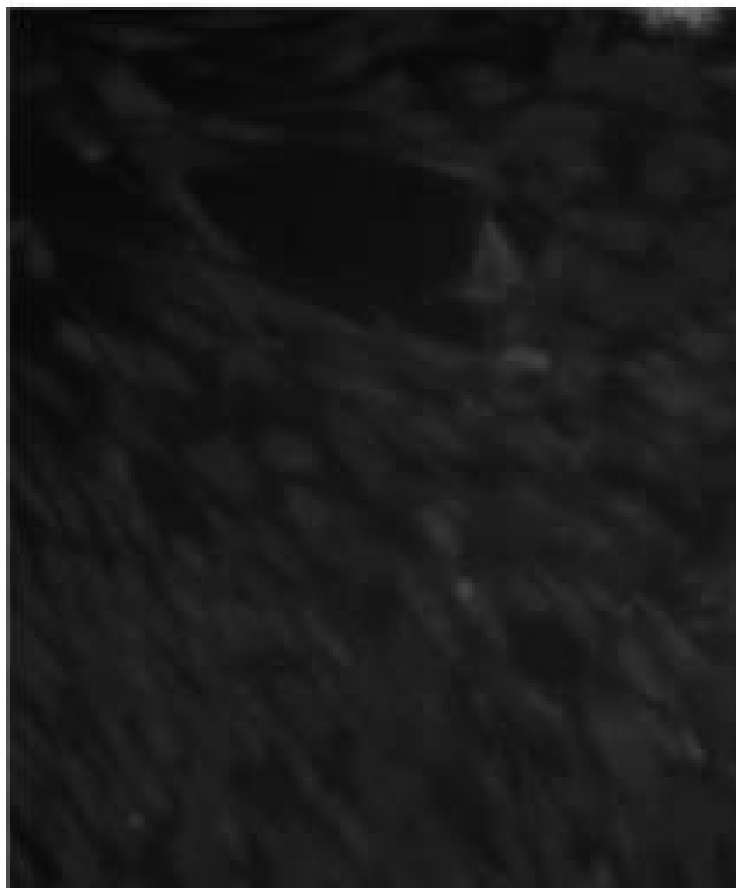

Fig. 3. Detection of CAEV antigen by Immunofluorescence test. FLL cells inoculated with carpal joint fluid from a goat with arthritis a nd non-infected FLL cells were incubated with the control positive serum for AGID and stained with FITC-conjugated rabbit IgG fract ion to goat IgG respectively. a) Inoculated FLL cells. Formed syncytium was stained with Immunofluorescence. b) Control FLL cells. No fluorescence was observed. 


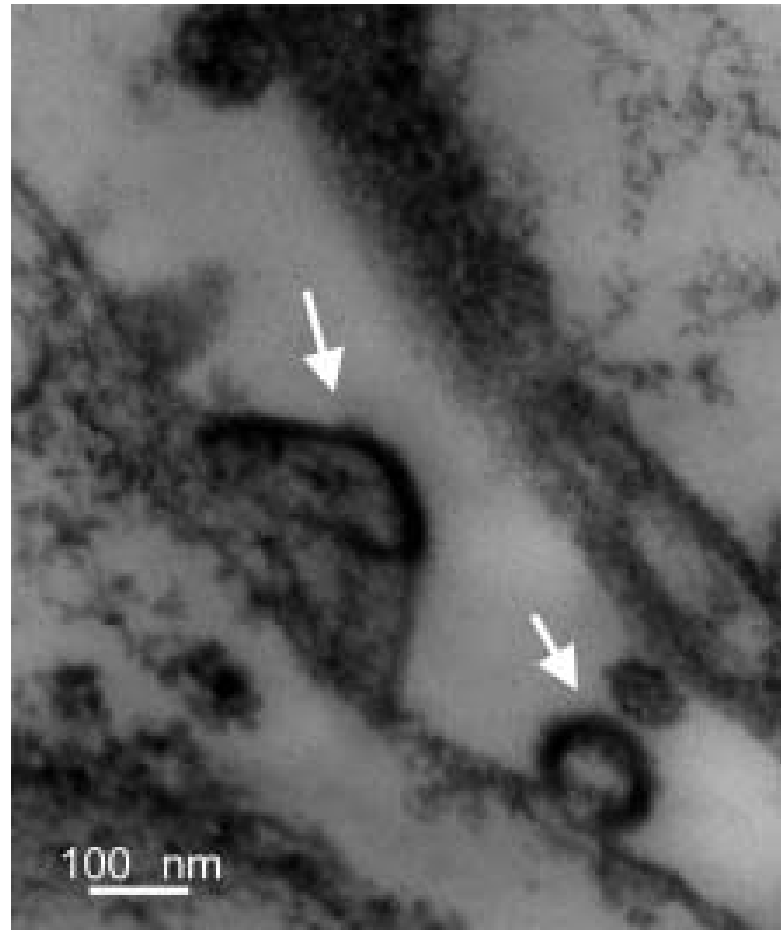

Fig. 4. CAEV observed in FLL cells co-cultivated with PBL. Virus is budding from the plasma membrane. Bar $=100 \mathrm{~nm}$. was amplified from the control FLL cells. One of the second PCR products, that amplified from the DNA extracted from PBL of goat No. 40, was selected, and was sequenced. The sequence homology in gag region of that to CAEV-Co strain (Gene bank No.M33677) [22] and MVV(Gene bank No.M60610) [23] were $93.0 \%$ and $86.1 \%$, respectively (Fig. 6).

\section{DISCUSSION}

Since the goats on the farm showed clinical symptoms characterized by arthritis of carpal joints and occasionally by pneumonia, they were suspected to be infected with CAEV [6, 7, 15, 16, 24]. Since we did not have cell cultures that could produce high concentrations of CAEV, a serological test was done using MVV as the antigen in the AGID test. Antibody-positive animals were detected on the farm at a high rate. This result indicated that they were infected with a lentivirus related to MVV. However, though the goats infected experimentally with MVV sometimes show the clinical symptoms of arthritis [4], natural infections of MVV are seldom observed among goats [17]. Furthermore, the DNA sequences of PCR products had about $93 \%$ homology to the reported CAEV genome while homology to the reported MVV genome of it was only $86 \%$. Thus, the disease was identified as CAEV infection, not MVV infection. This is the first report of CAEV infection in Japan.

Since FLL cells inoculated with carpal joint fluid of

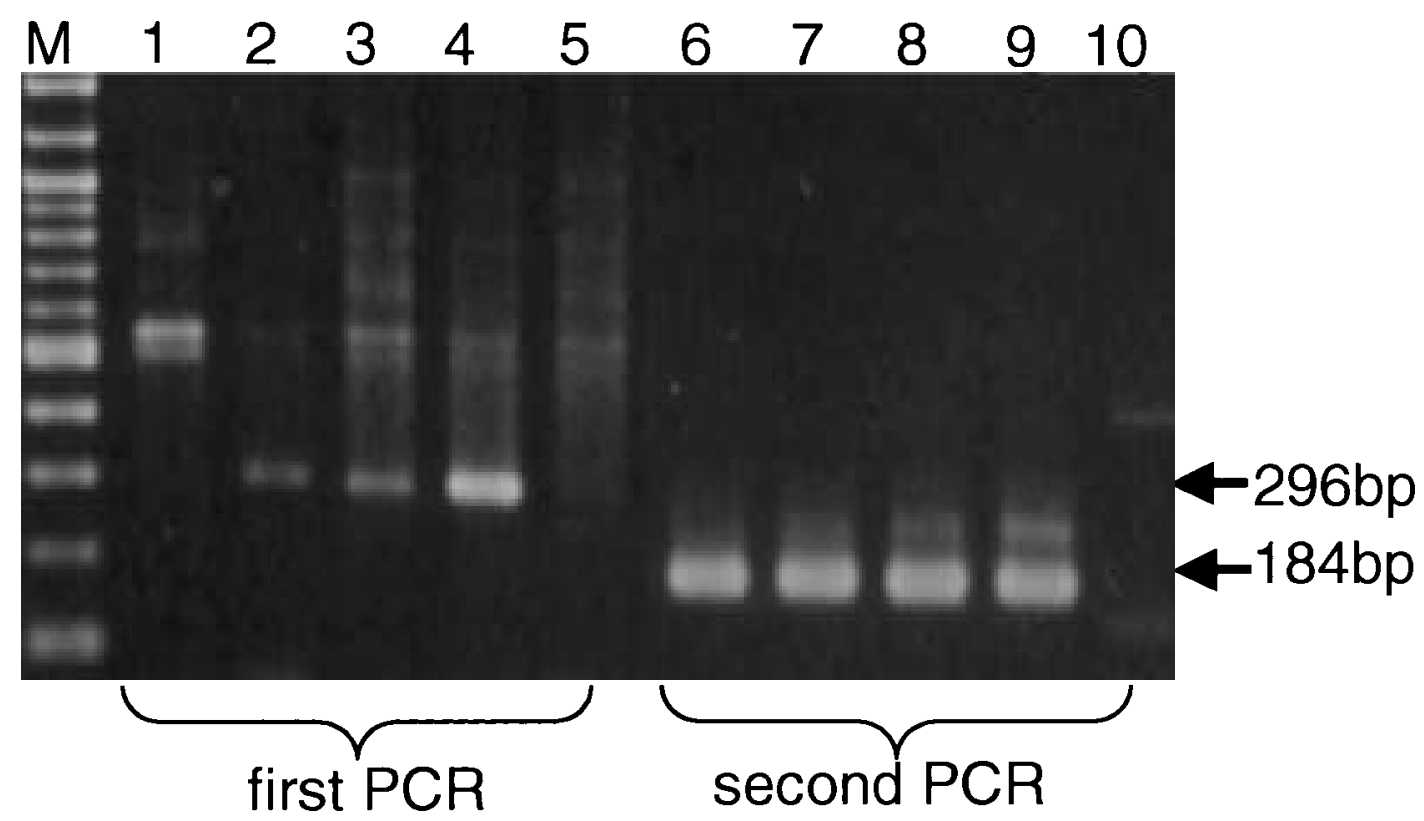

Fig. 5. PCR products of isolated virus, maedi virus and visna virus. $296 \mathrm{bp}$ fragments were amplified after the first PCR, and $184 \mathrm{bp}$ fragments were amplified after the second PCR. Lane 1 and 6: PBL from goat No. 40 that suffered from arthritis and necropsied. Lane 2 and 7: FLL cells co-cultivated with the PBL. Lane 3 and 8: FLL cells infected with Maedi virus. Lane 4 and 9: FLL cells infected with Visna virus. Lane 5 and 10: Non-infected FLL cells. 


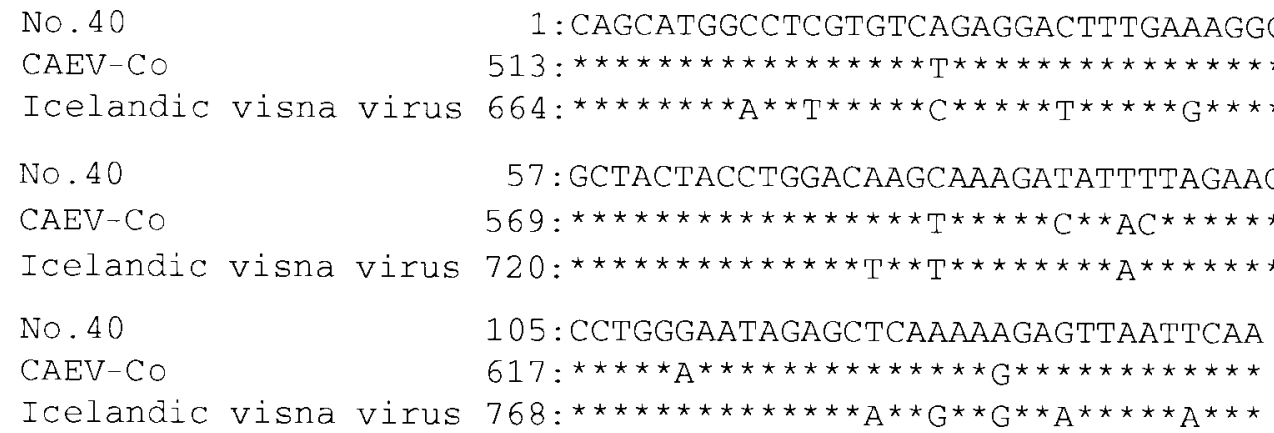

Fig. 6. Alignment of nucleotide sequences ( $184 \mathrm{bp}$ ) of the PBL from goat No. 40 with reported CAEV and Visna virus. Asterisks indicate identity between them.

infected goats formed syncitia and became PCR positive, and since the goats inoculated with the culture fluid of these FLL cells became antibody positive, the virus was clearly isolated from the goats and serially propagated in the FLL cell cultures. Therefore it is possible to use FLL cells for the isolation of CAEV, though the cells might be less sensitive to CAEV compared to cells originating from the goat.

It was not clarified how the goats became infected with CAEV. The workers on the farm noted that the arthritis and other symptoms had sometimes been observed among the goats since several years earlier. The main work of the farm is breeding of goats and goats have been frequently imported from abroad for their genomic improvement. It is likely that goats subclinically infected with CAEV were introduced accidentally to the farm and that the infection spread among the flocks subclinically, because imported goats have only been diagnosed by clinical signs in the animal quarantine service station.

There were many antibody-positive animals among the Shiba goats, though they were bred in Japan. However, in their original farm, which belongs to the University of Tokyo, all of Shiba goats kept on there were seronegative. Thus, they were infected with the virus from goats of another breed on the farm in Nagano prefecture.

A serological survey was subsequently conducted on 16 farms in Ibaraki prefecture. Positive goats were only detected on two farms where goats transferred from the farm in Nagano prefecture existed. However, some goats that did not originate from the farm in Nagano were found to be positive on both farms. These results indicated that the disease was not very contagious, but spread gradually from goat to goat.

At present the rate of infected goats and their distribution in Japan is not clear. However, the life span of the goat is not so long. Thus, it is not so hard to eradicate CAEV among goats compare to the BLV among cattle, if the vertical and horizontal transmission routes of the disease can be cut by isolating the newborn from the mothers before they take colostrum and by separating positive goats from negative goats $[3,11,19-21]$. Such eradication programs were tested for maedi visna [9, 17]. However, it is not easy to correctly identify infected goats [7]. Since CAEV-infected goats could be detected by the AGID test and PCR, the sensitivity of both tests is not sufficient. The results of the present study could not show a significant correlation between the serological test and PCR (Table 1). Therefore, there might be some goats infected with CAEV but not detected by either test. More sensitive diagnosis is required to detect subclinically infected goats and completely eradicate the disease from Japan.

ACKNOWLEDGEMENTS. We would like to thank Dr. M. Onuma (Hokkaido University) and Dr. D. P. Knowles, Jr. of the OIE Reference Laboratory for CAE and maedi-visna (Animal Disease Research Unit, USDA, ARS, Washington State University) for supplying the MVV and antiserum, and Dr. A. Okada and Miss K. Nakazawa for their skillful EM observation. We are also grateful to Mr. K. Barrymore for his critical reading of the manuscript. This work was supported in part by a special grant from the National Institute of Animal Health and Urgent Countermeasures Budget from the Ministry of Agriculture, Forestry and Fisheries of Japan.

\section{REFERENCES}

1. Adams, D. S., Crawford, T. B., Banks, K. L., McGuire, T. C. and Perryman, L. E. 1980. Immune responses of goats persistently infected with caprine arthritis-encephalitis virus. Infect. Immun. 28: 421-427.

2. Adams, D. S., Oliver, R. E., Ameghino, E., DeMartini, J. C., Verwoerd, D. W., Houwers, D. J., Waghela, S., Gorham, J. R., Hyllseth, B., Dawson, M., Trigo, F. J. and McGuire, T. C. 1984. Global survey of serological evidence of caprine arthritis-encephalitis virus infections. Vet. Rec. 115: 493-495.

3. Adams, D. S., Klevjer-Anderson, P., Carlson, J.L., McGuire, T. C. and Gorham, J. R. 1983. Transmission and control of caprine arthritis-encephalitis virus. Am. J. Vet. Res. 44: 16701675 .

4. Banks, K. L., Adams, D. S., McGuire, T. C. and Carlson, J. 1983. Experimental infection of sheep by caprine arthritisencephalitis virus and goats by progressive pneumonia virus. Am. J. Vet. Res. 44: 2307-2311.

5. Cheevers, W. P., Roberson, S., Klevjer-Anderson, P. and 
Crawford, T. B. 1981. Characterization of caprine arthritisencephalitis virus: a retrovirus of goats. Arch. Virol. 67: 111117.

6. Crawford, T. B. Adams, D. S., Cheevers, W. P. and Cork, L. C. 1980. Chronic arthritis in goats caused by a retrovirus. Science 207: 997-999.

7. Crawford, T. B. and Adams, D. S. 1981. Caprine arthritisencephalitis: clinical features and presence of antibody in selected goat populations. J. Am. Vet. Med. Assoc. 178: 713719 .

8. Cutlip, R. C., Jackson, T. A. and Laird, G. A. 1977. Immunodiffusion test for ovine progressive pneumonia. Am. J. Vet. Res. 38: 1081-1084.

9. De Boer, G. F., Terpstra, C., Houwers, D. J. and Hendriks, J. 1979. Studies in epidemiology of maedi/visna in sheep. Res. Vet. Sci. 26: 202-208.

10. Fieni, F., Rowe, J., Van Hoosear, K., Burucoa, C., Oppenheim, S., Anderson, G., Murray, J. and Bon Durant, R. 2002. Presence of caprine arthritis-encephalitis virus (CAEV) infected cells in flushing media following oviductal-stage embryo collection. Theriogenology 57: 931-940.

11. Houwers, D. J., König, C.D.W., De Boer, G. F. and Schaake, Jr. J. 1983. Maedi-visna control in sheep. I. Artifical rearing of colostrum-deprived lambs. Vet. Microbiol. 8: 179-185.

12. Knowles, D. P. Jr., Evermann, J. F., Schropshire, C., Vander Schalie, J., Bradway, D., Gezon, H. M. and Cheevers, W. P. 1994. Evaluation of agar gel immunodiffusion serology using caprine and ovine lentiviral antigens for detection of antibody to caprine arthritis-encephalitis virus. J. Clin. Microbiol. 32: 243-245.

13. Kono, Y., Arai, K., Sentsui, H., Matsukawa, S. and Itohara, S. 1986. Protection against bovine leukemia virus infection in sheep by active and passive immunization. Jpn. J. Vet. Sci. 48: $117-125$.

14. Kono, Y., Sentsui, H., Miyamoto, T., Morozumi, K. and Sakamoto, Y. 1982. Change in antibody titers in cattle infected clinically and subclinically with bovine leukemia virus. Int. J. Cancer 30: 655-657.

15. Narayan, O. and Cork, L. C. 1990. Caprine arthritis-encephalitis virus. pp. 441-452. In: Virus Infections of Ruminants
(Dinter, Z. and Morein, B. eds.), Elsevier Science Publishers B. V., Amsterdam, The Netherlands.

16. Narayan, O., Zink, M. C., Gorrell, M., Crane, S., Huso, D., Jolly, P., Saltarelli, M., Adams, R. J. and Clements, J. E. 1993. The lentiviruses of sheep and goats. pp. 229-255. In: Retroviridae, vol. 2. (Levy, J. A. ed.), Plenum Press, New York, U.S.A.

17. Petursson, G., Georgsson, G. and Palsson, P. A. 1990. Maedivisna virus. pp. 431-440. In: Virus Infections of Ruminants (Dinter, Z. and Morein, B. eds.), Elsevier Science Publishers B. V. Amsterdam, The Netherlands.

18. Rimstad, E., East, N. E., Torten, M., Higgins, J., DeRock, E. and Pedersen, N. C. 1993. Delayed seroconversion following naturally acquired caprine arthritis-encephalitis virus infection in goats. Am. J. Vet. Res. 54: 1858-1862.

19. Rowe, J. D., East, N. E., Thurmond, M. C. and Franti, C. E. 1991. Risk factors associated with caprine arthritis-encephalitis virus infection in goats on California dairies. Am. J. Vet. Res. 52: $510-514$

20. Rowe, J. D., East, N. E., Franti, C. E., Thurmond, M. C., Pedersen, N. C. and Theilen, G. H. 1992. Risk factors associated with the incidence of seroconversion to caprine arthritisencephalitis virus in goats on California dairies. Am. J. Vet. Res. 53: 2396-2403.

21. Rowe, J. D., East, N. E., Thurmond, M. C., Franti, C. E. and Pedersen, N. C. 1992. Cohort study of natural transmission and two methods for control of caprine arthritis-encephalitis virus infection in goats on a California dairy. Am. J. Vet. Res. 53: 2386-2395.

22. Saltarelli, M., Querat, G., Konings, D. A. M., Vigne, R. and Clements, J. E. 1990. Nucleotide sequence and transcriptional analysis of molecular clones of CAEV which generate infectious virus. Virology 179: 347-364.

23. Sonigo, P., Alizon, M., Staskus, K., Klatzmann, D., Cole, S., Danos, O., Retzel, E., Tiollais, P., Haase, A. and Wain-Hobson, S. 1985. Nucleotide sequence of the visna lentivirus: relationship to the AIDS virus. Cell 42: 369-382.

24. Zink, M. C., Yager, J. A. and Myers, J. D. 1990. Pathogenesis of caprine arthritis-encephalitis virus. Cellular localization of viral transcripts in tissues of infected goats. Am. J. Pathol. 136: 843-854. 